\title{
ПРАВОБІЧНИЙ ПОШИРЮВАЧ У ФУНКЦІЇ МАРКЕРА ЛОКАТИВНОЇ СЕМАНТИКИ НА РЕЧЕННЄВОМУ ТЛІ
}

У статті схарактеризовано механізм формування семантики «носій прочесуальної ознаки + прочесуальна ознака + просторові межі реалізачії прочесуальної ознаки», яку передають речення структурної моделі Sub + Praed + Adv loc, з опертям на правобічний поширювач, репрезентований у вигляді прийменниково-іменникової конструкції. Доведено, що одним з основних маркерів диференційованих значень «місие дії», «напрям руху» або «илях руху» є програмований предикатом правобічний поширювач. На прикладі конкретних речень з локативно-статичним, локативно-директивним і локативно-транзитивним типом детермінаціі з'ясовано роль іменниківзаповнювачів позиції Adv [Prep + N] loc у конституюванні конкретного різновиду значення.

Ключові слова: правобічний токативний почирювач, іменники-заповнювачі правобічної позиції, первинні (вторинні) прийменники, маркери просторової семантики, речення з токативним типом детермінації.

Stepanenko M. Right-hand Extender Functioning as the Locative Semantics Marker in the Context of a Sentence. The article is devoted to the analysis of sentences with the semantic description " a carrier with a procedural feature + procedural feature + spatial boundaries of the implementation of a procedural feature" in terms of the interaction of their semantic-syntactic and formal-grammatical levels. The study mainly focuses on the role of the right-hand extenders in the sentences with the structural model Sub + Praed + Adv loc as they contribute to the formation of a certain type of differentiated semantics which represents of one of the generic locative values "place of action", "direction of movement: start or finish", "path of movement". The structural model [Sub + Praed + Adv [PID / PIDI / PIDO + Ninst] loc [stat], Sub + Praed + Adv [ZA + Nass] loc [dir], Sub + Praed + Adv [Ninst] loc [trans]) has been singled out and its instantiations have been analysed. This analysis has made it possible to establish the role of the constitutive positions, in particular the right one (Adv [Prep + Nx or Nx] loc) in the formation of a specific type of locative meaning. It has been proved that it is the right-hand extender determined by the verb predicate as having some valency which is the marker of a particular differentiated meaning "place of action", "direction of movement", "path of movement" at the semantic level. This extender can be used either independently (Adv [Ninst] loc [trans]) or with a preposition (Adv [Prep $+N x]$ loc [start, dir or trans]). For this purpose, semantic types of nouns have been distinguished, their correlations with differentiated meanings have been detected. An important distinctive function of the verb predicates has been observed: the lexemes which name the purposeful movement are regularly used in the sentences with directive and transitive meanings while the lexemes that 
denote static action or non-purposeful movement are used in the sentences with the meaning of the place of action. Besides, it has been noted that the category of number of the noun which takes the right-hand position in the analysed structural model or the context in general can identify the meaning. Close attention has been paid to locative prepositions and their ability to contribute to sentence constitution. The primary and secondary prepositions have been distinguished, the peculiarities of both have been described. It has been highlighted that the preposition functions as a mediator between the verb predicate and the noun that fills in the right-hand position. The preposition is included into the semantics of the predicate extender. Moreover, the preposition often takes on the role of an indicator of locative relations. The latter function is characteristic of secondary prepositions which have a special semantic status because they retain a genetic connection with their motivating words, especially nouns and adverbs.

Key words: right-hand locative extender, nouns fillings in the right-hand position, primary (secondary) prepositions, spatial semantics markers, sentences with locative type of determination.

\section{Вступ}

Поліфункційні відношення локативності, які репрезентують речення структурної моделі Sub + Praed + Adv loc із загальним семантичним описом «носій процесуальної ознаки + процесуальна ознака + просторові межі реалізації процесуальної ознаки», представлені розлогим спектром диференційованих значень. Конкретні види цих значень, можливі їхні родові утворення з різних позицій досліджували вітчизняні (І. Вихованець, К. Городенська, В. Войцехівська, А. Загнітко, 3. Іваненко, Н. Іваницька та ін.) і зарубіжні (В. Гак, Г. Гжегорчикова, Б. Тошович, І. Шатуновський, Є. Владимирський, М. Всеволодова, В. Глухих, О. Кібрик, Л. Засоріна, Т. Засухіна, В. Нікітін та ін.) мовознавці. Проблема маркерів локативності не стала предметом прискіпливої уваги лінгвістів, отже, вона є актуальною.

Метою статті є з'ясування ролі заповнювачів правобічних позицій речень-репрезентантів структурної моделі Sub + Praed + Adv loc у формуванні закріпленого за ними конкретного різновиду статичної, директивної або транзитивної локативності.

\section{Методи дослідження}

У процесі аналізу синтаксичних структур із просторовим типом детермінації використано методики дистрибутивного, компонентного, функційно-трансформаційного аналізу, прийоми дефініційного, семно-компонентного аналізу. 


\section{Виклад основного матеріалу}

Диференційовані значення, указуючи на чітко визначене місце реалізації процесуальної ознаки, її напрям руху, представлений стартовим і фінішним набором, і шлях руху, об'єднуються в три семантичні типи: 1) «місце дії, 2) «напрям руху», 3) «шлях руху». Пор.: 1) Щось руділо вдовж паркану (А. Головко) («місце дії» $\rightarrow$ «дія відбувається в просторі, що має протяжність у довжину»); 2) Палилюлька вийшов з-за столу (М. Стельмах) («напрям руху: старт» $\rightarrow$ «напрям руху з протилежного боку локативного орієнтира»); Кольщьо рано пішов над Черемош (М. Павлик) («напрям руху $\rightarrow$ фініш» - «напрям руху в бік локативного орієнтира»); 3) Через Францію я добивався додому (С. Пушик) («шлях руху» $\rightarrow$ «шлях руху з метою виходу за межі локативного орієнтира»).

Що ж до маркерів локативності, то спостережено таку закономірність: на рівні одного значення роль основного виразника того або того типу просторовості виконує правобічний компонент (іменник, прийменник, іменник і прийменник одночасно), а на рівні різних значень - основний носій валентності, тобто предикат, який формує склад речення, передбачає його компонентну організацію - лівобічних та правобічних поширювачів. Почасти дистинктивну функцію може перебирати на себе граматична форма числа припредикатних членів Adv [Nx] loc, Adv [Prep + Nx] loc, а також контекст.

За кожним типом диференційованих планів змісту як органічних складників родових значень «місце дії», «напрям руху», «шлях руху» закріпився свій лексико-семантичний набір експлікаторів позицій Sub, Praed та Adv loc. За незначним винятком корпус дієслівпредикатів залишається відносно стабільним: основним виразником семантики «місце дії» $є$ статичні дієслова та дієслова нецілеспрямованого руху. Структурування значень «напрям руху» та «шлях руху» пов'язане головно з вербативами цілеспрямованого руху. 3 особливим акцентом вияскравимо, що йдеться не про якусь константну тенденцію, а про загальні риси збіжності.

Демаркаційну роль правобічного конституента виявлено передусім у синтаксичних конструкціях полісемантичної структури. Сказане промовисто ілюструє речення структурної субмоделі Sub + Praed + Adv [ПІД / ПІДІ / ПІДО + Ninst] loc [stat], яке передає три диференційовані значення загальної семантики «носій процесуальної 
ознаки + процесуальна ознака + місце реалізації процесуальної ознаки»: 1) «носій процесуальної ознаки + процесуальна ознака + місце реалізації процесуальної ознаки: дія відбувається нижче від локативного орієнтира», 2) «носій процесуальної ознаки + процесуальна ознака + місце реалізації процесуальної ознаки: дія відбувається на певній віддалі від локативного орієнтира», 3) «носій процесуальної ознаки + процесуальна ознака + місце реалізації процесуальної ознаки: дія відбувається за протилежним або зворотним боком локативного орієнтира».

Денотативний план «дія відбувається нижче від локативного орієнтира» аналізована синтаксична структура послідовно зберігає тоді, коли прогнозовану предикатом позицію справа заповнюють речовинні іменники на зразок вода, лід, крига, мул, земля, пісок, ллей, глина, солончак, чорнозем, каміння, порода. Правобічний компонент Adv [ПІД / ПІДІ / ПІДО + N (вода, земля, пісок, сніг ...) inst] loc [stat] актуалізує сему «повне занурення предмета, що локалізується, у рідину» (Всеволодова, \& Владимирский, 1982: 69): ... він оживає під землею (П. Загребельний); Під льодовою покрівлею ... біжать водяні краплі (Дніпрова Чайка). Розряд припредикатних поширювачів доповнюють субстантиви - найменування різноманітних предметів або їхніх частин, що мають нижній і верхній бік (стіл, ліжко, лава, скриня, шаба, судник, парасоля, автобус, віз, дах, листок [рослини]), окремих споруд, призначених для переміщення, переходу, переїзду (мicm, естакада, тунель), окремих частин тіла людини або тварини (ноги, руки, пахва, копита): Ти під возом лежии боєвим (Олег Ольжич); Вони проклали шнур під мостом (Я. Баш); Під оком у нього затіпалась жилка (В. Малик). До цього розряду входять також лексеми на позначення конкретних предметів на зразок скло, покривало, ковдра, рядно, простирадло: Під склом лежали ... списи (І. Цюпа); Тихо лежить він ... nід ковдрою (3. Тулуб). Крім вирізнених іменників, у припредикатній позиції зафіксовано також субстантиви на зразок небо, хмара, земна куля, які називають необмежений простір: Під синім небом Украйни зазолотилися жита (В. Крищенко); ... я стояв під зірками (В. Сосюра). Нарешті, правобічну позицію можуть займати лексеми на взірець текст, підпис, абзаи: Такчого ж ти і всі ваші люди не ставите підписів nid актом? (М. Стельмах). Специфіка речень, утворюваних за участю цих іменникових лексем, полягає в тому, що для репрезентантів 
лівобічної та правобічної позиції характерне семантичне узгодження, пор.: Печатка стоїть під текстом [заявою, розпискою, датою, підписом, иифрами ...].

Лексико-семантичний склад заповнювачів позиції Adv [ПІД / ПІДІ / ПІДО + Ninst] loc [stat] речень-реалізаторів локативно-статичного диференційованого значення «дія відбувається на певній віддалі від локативного орієнтира» обмежений. Він охоплює власні й загальні назви населених пунктів, окремих просторових понять, для яких сема «нижня і верхня частина» $є$ індиферентною. Це, зокрема, найменування типів ландшафтів за рослинністю: Я був під Переяславом, під Черніговом, під Путивлем (В. Малик); Лежать під лісом люди на траві (Л. Костенко); ... під косогором джерело воркує (М. Сингаївський).

В окремому валентному оточенні вирізнені диференційовані значення чітко не розмежовуються, навіть об'єднуються: $X$ лежав [майнув ...] під деревом [стовпом, парканом, стогом, магазином, дверима ...]. Синкретизм з'являється тоді, коли припредикатну позицію разом із прийменником під / піді / підо формують іменники, у значеннєвій структурі яких не експліцитно, а імпліцитно закладена сема «нижня і верхня частина». Ідеться про лексеми - назви будівель та їхніх частин (хата, клуня, стіна, піч), штучних отворів у стіні приміщення, споруди або огорожі (вікно, двері, брама, люк), огорож (пар-

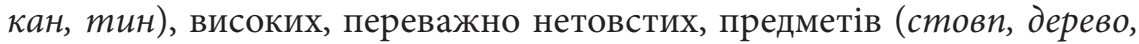
клен, антена), частин типів поверхонь (гора, косогір): Хворий схилився під хатою (І. Багряний); Старі гомонять під ворітьми (М. Коцюбинський); Під скелею росли лози (І. Нечуй-Левицький). Функцію визначника ядерності або периферійності якогось із диференційованих значень можуть виконувати інші мовні засоби, насамперед число іменників-заповнювачів правобічної позиції, інтенсифікувальні лексеми, які, розширюючи компонентний склад речення, уточнюють план змісту правобічного конституента. Якщо субстантиви - назви дерев, типів поверхонь набувають форми множини, основним змістом речення $є$ повідомлення про локалізацію об’єкта (предмета або істоти) на певній віддалі від просторового орієнтира. Аналогійний семантичний опис мають реченнєві структури, що містять у своєму складі інтенсифікувальні лексеми. Пор.: Х лежав під деревами [вербами, горами, косогорами ...], Х плакав під самим [аж під, близько під ...] парканом [стіною ...]. 
Лексико-семантичною обмеженістю щодо вибору заповнювачів позицій Adv [ПІД / ПІДІ / ПІДО + Ninst] loc [stat] наділені реченнярепрезентанти семантики «носій процесуальної ознаки + процесуальна ознака + просторові межі реалізації процесуальної ознаки: дія відбувається за протилежним або зворотним боком локативного орієнтира». Іменники, які з прийменником під / піді / підо формують локативно-статичний поширювач, охоплюють назви одягу, частин або деталей його (свита, фартух, пальто, піджак, костюм, комірець, пояс, ремінь, застібка), деяких поверхонь, покриттів, шарів (штукатурка, шпалера, шкіра): Вона ховала під одежею книжку (І. Микитенко); ... під шкірою нервово затіпавсь ... бугорок (М. Стельмах). Необхідною умовою для вираження описуваного значення $є$ реалізація субстантивами-поширювачами семи «вертикальне розташування». Якщо вони актуалізують сему «горизонтальне розташування», синтаксичні конструкції можуть передавати інше диференційоване значення - «дія відбувається нижче від локативного орієнтира». Пор.:

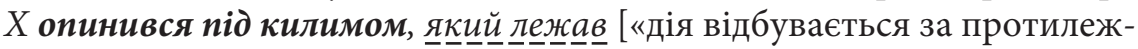
ним (зворотним) боком виробу для вкривання підлоги»] і Х опинився

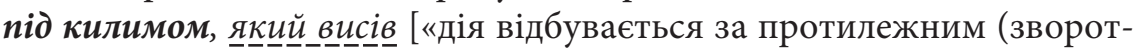
ним) боком виробу для оздоблювання стін» і «дія відбувається нижче від локативного орієнтира - виробу для оздоблювання стін»]. Точно встановити тип реалізованого значення допоможе контекст - ще один з можливих, а подеколи й домінувальних засобів ідентифікування просторової семантики.

Аналогійну картину стосовно маркерів локативності спостережено на рівні речень із семантикою директивності (cmapm, бінін, cmapm + фiнiш). Це можна виразно проілюструвати на прикладі речень структурної субмоделі Sub + Praed + Adv [3A + Nacc] loc [dir]. Семантичні конструкції з правобічним конституентом Adv [3A + $\mathrm{Nacc}$ loc [dir] мають такі семантичні описи: 1) «носій процесуальної ознаки + процесуальна ознака + напрям реалізації процесуальної ознаки: кінцевий пункт руху: напрям руху за межі локативного орієнтира»; 2) «носій процесуальної ознаки + процесуальна ознака + напрям реалізації процесуальної ознаки: кінцевий пункт руху: напрям руху за протилежний або зворотний бік локативного орієнтира»; 3 ) «носій процесуальної ознаки + процесуальна ознака + напрям реалізації процесуальної ознаки: кінцевий пункт руху: напрям руху 
на локативний орієнтир, що являє собою об’єкт діяльності». Перше значенням виникає тоді, коли роль обставинного поширювача виконують іменники - назви різноманітних обмежених та необмежених просторів. Це передусім найменування водних об’єктів (море, озеро, Байкал, Дніпро), функційних територій (пасіка, полігон, ферма, ивинтар), місць громадського користування (перон, порт), місць громадського відпочинку (зоопарк), типів місцевостей (бір, гай, діброва, ліс), населених пунктів і їхніх частин (село, Борислав, подвір'я), протяжних реальних та умовних горизонтальних об'єктів (щлях, кордон): ... гуиули За океан пливли (А. Дімаров.); Чоловік провів його за ивинтар (А. Свидницький); Ой пішов милий за ліс (Українська народна пісня); ... Марія Олександрівна ... за кордон поїхала (О. Іваненко). Друге значення регулярно формують субстантиви - найменування фасадних предметів, предметів, що мають зовнішній, лицьовий бік. Сюди слід уналежнити лексеми на позначення житлових, господарських або будь-яких інших споруд та їхніх частин (хата, клуб, причілок (розм.), поріг, стіна), зворотних сторін яких-небудь просторових об'єктів (борт, корма), різноманітних предметів побуту та їхніх частин (скриня, шафа, ліжко), частин, деталей одягу (комір, поясок, ремінь), отворів у спорудах, проїздів або проходів між будівлями (вікно, ворота, хвіртка, брама), огорож (тин, паркан, палісадник, частокіл, огорожа), природних об’єктів, які вивищуються над поверхнею (гора, скеля), різноманітних об'ємних предметів, у яких зворотний бік установлено щодо спостерігача (дерево, стовбур, куш, стовп, завіса): Син забіг за оселю (М. Коцюбинський); Твій батько вийшов за поріг (М. Бажан); Кутузов зайшов за стіл (І. Багряний); ... [він] заховав люльку за ремінь (О. Кобилянська); Богослов випровадив його аж за ворота (А. Свидницький); I [я] за мур переплигнув (Т. Осьмачка); А старий ... поплентався за скелю (Я. Баш). Заповнювачами позиції $\mathrm{Adv}[3 \mathrm{~A}+\mathrm{Nacc}]$ loc [dir] можуть бути також іменники ріг та повоpom, які функціюють самостійно або в складі дескрипції: ... [вони] звернули за ріг (О. Десняк). В особливу групу виокремлено речення 3 поширювачами - назвами явищ природи (туман, дим, хмара) й найменуваннями на зразок обрій, горизонт, крайнебо, оскільки для цих іменників поняття «лицевий / зворотний бік», «фасад» $є$ індиферентними: Місяць за хмари сховався (В. Сосюра ); Сонце ... закотиться за кичеру (Г. Хоткевич); Сунуть за обрій ... хмарини (П. Мовчан). 
Діапазон правобічних поширювачів, які беруть участь у формуванні третього значення, не виходить за рамки іменників, що номінують моно- або поліспеціалізовані предмети чи знаряддя праці (cmiл, верстат, рояль, піаніно, кулемет, кермо, штурвал, стерно, пульт): ... він ... лягав за кулемет (М. Руденко); Він сідає за рояль (Ю. Щербак); Гість сів за піаніно (Р. Горак); Сагайдак сів за стерно (С. Добровольський).

Важливо враховувати те, що правобічний просторовий поширювач бере визначальну роль у формуванні того або того диференційованого значення, але не постає як єдино можливий маркер локативності. Цю функцію може частково перебирати на себе предикат із притаманним йому спектром категорій, із властивою йому морфемною будовою. У лінгвістиці усталилася думка, за якою в реченнях з дієсловами-предикатами на зразок сідати, лягати, ховати, класти, виливати, ставити, які, маючи здебільшого безпрефіксну форму, виражають відносно обмежену інтенсивність руху, відбувається нейтралізація значень «напрям реалізації процесуальної ознаки: кінцевий пункт руху» й «місце реалізації процесуальної ознаки», унаслідок чого правобічні поширювачі Adv [3A + Nacc] loc - носії семантики «напрям реалізації процесуальної ознаки: кінцевий пункт руху» - функційно зближуються з правобічними поширювачами $\mathrm{Adv}$ [3A + Ninst] loc - носіями семантики «місце реалізації процесуальної ознаки». При цьому не заперечено того факту, що їхні індивідуальні відтінки частково зберігаються (Вихованець, 1971: 78). Говорити про те, що «нейтралізація протиставлення знахідного з прийменником за й орудного з прийменником за (значення напрямку і місця дії)» вже завершилася і що ці конструкції перебувають у реченні на правах рівнозначних поширювачів (там само), немає достатніх підстав. Є більші аргументи дотримуватися іншого трактування: у реченнях з виокремленими вище заповнювачами предикатної позиції обставинні поширювачі Adv [3A + Nacc] loc спеціалізуються на репрезентації значення напрямку руху, а не місця дії. Цьому значенню притаманна особлива природа, оскільки воно об'єктивоване не у власне директивному вияві, а містить відтінок місця дії, тобто воно прямує до того значення, яке закріплене за правобічним поширювачем Adv [3A + Ninst] loc. Дієслова-предикати сідати, лягати вказують на зміну місцеположення суб'єкта в просторі, на те, що динамічна дія переходить у статичну. 
Цей процес стає очевидним тоді, коли основний носій валентності набуває форми доконаного виду. Пор.: Х сідає за кермо (итурвал) [займає місце на сидінні й буде керувати рухом автомашини, судна, літака тощо] й $X$ сів за кермо (штурвал) [зайняв місце на сидінні й може керувати рухом автомашини, судна, літака тощо].

Правобічний локативний поширювач ідентифікує не лише статичне та директивне, а й транзитивне значення, що з усією повнотою підтверджують речення структурної субмоделі Sub + Praed + Adv [Ninst] loc [trans], які мають такі описи: 1) «носій процесуальної ознаки + процесуальна ознака + шлях реалізації процесуальної ознаки: шлях руху через внутрішні межі локативного орієнтира, що являє собою отвір»; 2) «носій процесуальної ознаки + процесуальна ознака + шлях реалізації процесуальної ознаки: шлях руху по поверхні локативного орієнтира, що являє собою відкритий або внутрішній простір». Лексико-семантичний склад іменників - заповнювачів припредикатної позиції в реченнях обох семантичних типів лімітований, причому жорсткіша лексико-семантична селекційність характерна для синтаксичних конструкцій з першим значенням. Правобічні поширювачі об'єднані семою «природний або штучний отвір», лексичним ідентифікатором якого $є$ іменник отвір - «пусте, відкрите місце в чому-небудь суцільному». Цей розряд припредикатних членів можна диференціювати на три семантичні типи: 1) назви отворів узагалі, без указівки на їхній природний або штучний характер (отвір, діра, дірка, щілина, пробоїна, шпарина, відтулина (розм.), хід); 2) найменування штучних отворів у стіні приміщення, споруди, в огорожі, між будівлями й т. ін. (вікно, вікнина, кватирка, двері, ворота, брама, хвіртка, верх [«димар»], бовдур, димар, димохід, лаз, лазівка, люк); 3) номінування природних отворів на тілі людини або тварини (горло, ніс, ніздрі, рот, уста, вуха (вухо), зябра): ... феї зникають чорним ходом (В. Підмогильний); Вбігали [вони] в алтар ... дверима (В. Барка); ... [Сагайдачний] переліз вікном у садок (А. Чайковський); Він виглянув вікном (I. Франко); ... дим бовдурами повалив (I. Франко); ... комином завсігди чарівниці вилітали (П. Франко); Але пішла горлом і носом кров (Літературна Україна). Іменники другої і третьої груп функціюють здебільшого без поширювачів, тоді як субстантиви першої групи досить часто одержують конкретизацію з боку уточнювальних слів, з якими утворюють дескрипцію на зразок Adjx + Subx, 
оскільки через свою інформативну недостатність потребують цієї конкретизації в певних умовах.

Реалізація другого значення пов'язана з правобічними поширювачами, що охоплюють семантичні групи іменників на позначення 1) наземних, підземних, водних, повітряних шляхів сполучення (автострада, брід, брук, бруківка, бульвар, вулиия, гостинець (заст.), дорога, дамба, манівець (розм.), магістраль, міст, провулок, просіка, путь, путівец, стежка, траса, тракт (заст.), тротуар, пішохід (заст.), илях, повітряний коридор, тунель, східиі, драбина): ... Килина йде пішоходом (Х. Алчевська); Подалися [хлопиі] трускавецьким трактом до Гірки (П. Франко); Плили [ми з тобою] ... иляхом водяним (Леся Українка); 2) ділянок земного рельєфу (болото, долина, вал, берег, узгір'я, гай, гора, ліс, луг, острів, парк, поле, рівнина, степ, суша, тундра, тайга): ... степом їхали ... тачанки (О. Гончар); Він не піднявся Ельбрусом (Б. Олійник); Вівці котилися горою ... (П. Франко); 3) водних об'єктів (море, океан, ріка): Тимко плив Ташанню (Г. Тютюнник); 4) космічних об’єктів (небо, небозвід): Зорі котилися небозводом (Д. Ткач); 5) континентів, країн, географічних областей, населених пунктів і їхніх частин (Австралія, Америка, Європа, Україна, місто, село, селище, хутір, столиия, район, двір, садиба, обійстя (діал.), подвір'я): Потяг мчить Молдовою (Українське слово); Поспішають Подолом трамваї (Г. Чубач); Кузь ... пішов двором (Г. Тютюнник); 6) будівель, споруд різного призначення і їхніх частин ( $x a m a$, кімната, сіни, світлиия, веранда, сарай, підлога): Раз проходив він каниелярією (Ю. Яновський); 7) типів покриву (вода, земля, рілля, суходіл, пісок, стерня, вруно): Ти ходиш ... суходолом (Л. Дмитерко); 8) спеціалізованих територій (сад, баштан, вигін, сінокіс, пасовище, полігон): Вони прямували вигоном (Ю. Бедзик); 9) місць громадського користування, відпочинку (базар, ринок, перон, зоопарк): ... Бубон ... гуляв пляжем (О. Чорногуз); 10) пристроїв для пересипання, пересування, переливання, транспортування чого-небудь (жолоб, труба): ... [вода] тече каналізаційною трубою (М. Руденко); 11) загальнопросторових понять (сторона, иентр, середина): Він прямував серединою (В. Малик).

Наголосимо ще раз, що поряд з іменником функцію локативного маркера регулярно виконують прийменники, для яких характерна семантична неоднорідність. Одні з них наділені інформативною 
недостатністю, тоді як інші виразно актуалізують той або той тип локативності. Значеннєва опозиція, про яку йдеться, детермінована генетичною природою прийменників. Семантика первинних (непохідних) прийменників є імпліцитною, вона реалізується в поєднанні з відмінковими формами іменників. Вторинні ж прийменники експліцитно репрезентують індивідуальні лексичні значення, які вони успадкували від мотивата - іменника, прислівника або дієприслівника. Призначення прийменника - прогнозувати відмінкову форму іменника й цим самим впливати на тип локативності на тлі валентної рамки Praed + Adv [Prep + N] loc і речення загалом.

Діахронно первинні прийменники опосередковано пов'язані з формуванням того або того диференційованого значення, вони вживаються здебільшого в реченнях полісемантичної будови. Так, прийменники в / у та на, що функціюють у складі речень структурних субмоделей Sub + Praed + Adv [B / У +Nloc] loc [stat $]$ i Sub + Praed + $\mathrm{Adv}[\mathrm{HA}+\mathrm{Nloc}]$ loc [stat], виявляють деякі специфічні особливості. Дослідники наголошували, що «прийменник на окреслює більш загально той предмет чи простір, в межах якого відбувається дія» (Колодяжний, 1960: 27), він «більше в'яжеться з назвами відкритого простору, а в (у) - закритого, більш обмеженого» (Булаховський, 1951: 88). Основна роль прийменника на, робить аргументований висновок А. С. Колодяжний, - указувати на поверхню предмета чи простору, де перебуває або відбувається щось, а прийменника в / у - означати перебування предмета або якоїсь чинності в середині чогось (Колодяжний, 1960: 128). Водночас не заперечується факт, що типи вирізнених протиставлень інколи нейтралізуються, унаслідок чого припредикатні члени Adv [B / У + Nloc] loc [stat] i Adv [HA + Nloc] loc [stat] або вживаються паралельно, або конкурують, «або на виступає там, де 6 ми сподівалися теоретично в: в інституті, але на курсах ... в театрі, але на концерті; в колгоспі, але на заводі» (Булаховський, 1951: 88).

Семантично відчутну роль у конституюванні локативної семантики виявляють первинні прийменники, що утворилися поєднанням двох або трьох первинних, але нерозкладні в граматичній системі української мови без втрати їхньої семантико-граматичної функції» (Вихованець, 2004: 331). Проілюструємо сказане на прикладі прийменника 3-3а, який безпосередньо причетний до конституювання значень «носій процесуальної ознаки + процесуальна ознака + напрям 
реалізації процесуальної ознаки: вихідний пункт руху: напрям руху 3-за меж локативного орієнтира» й «носій процесуальної ознаки + процесуальна ознака + напрям реалізації процесуальної ознаки: вихідний пункт руху: напрям руху з протилежного або зворотного боку локативного орієнтира». Цей прийменник, справедливо наголошує С. Є. Нікітіна, $є$ «триточковим, або орієнтованим», позаяк передбачає «реальну точку, перешкоду або проміжний пункт у просторі, а під третьою точкою розуміють спостерігача», вимагає «розрізнення фасаду й заднього боку в структурі предмета, названого залежним словом: із-за лісу (В) піднімається (А) місяиь (С) (імпліцитно присутній спостерігач)» (Никитина, \& Ярцева, 1979: 120-121]. Отже, процес ідентифікування значеннєвої природи речень з вирізненими першим та другим семантичними описами вимагає застосування таких критеріїв, як наявність / відсутність у просторового орієнтира фасаду й заднього боку та характер зв’язку, що існує між локативним орієнтиром і спостерігачем. Цілком природно план змісту іменників, які беруть участь у формуванні значеннєвої структури «напрям руху з-за меж локативного орієнтира», можна представити за допомогою загальної дефініції «простір, що не має фасаду, яскраво вираженого зовнішнього, лицьового боку». Розряд аналізованих поширювачів утворюють лексеми - найменування акваторій (море, озеро, Сиваш, 3бруч), функційних територій (танкодром, кладовище), місць громадського користування (парк, сквер), типів місцевостей (бір, гай, ліс), населених пунктів і їхніх частин (хутір, Чернігів, майдан, плома), реальних та умовних протяжних горизонтальних об'єктів (щлях, кордон): ... [я] прилітаю 3-за Єнісею, Вісли, з-за Дунаю (І. Драч); ... вибігли вони з-за цвинтаря (О. Кобилянська); Та звелася з-за лиману Хмара (В. Симоненко); Місяиь із-за лісу піднявся ощербком пригаслим (О. Гончар); 3-за хуторів висипали ... вороніцепи (О. Десняк); Вони приіздять аж із-за кордону (П. Загребельний). Значення іменників - заповнювачів правобічної позиції речень-репрезентантів плану змісту «напрям руху з протилежного або зворотного боку локативного орієнтира» - представляє загальна дефініція «простір, що має фасад, яскраво виражений зовнішній, лицьовий або протилежний, зворотний бік». 3-поміж них виділено субстантиви - найменування приміщень різного призначення і їхніх частин, споруд різного типу (будинок, сарай, школа, крамниия, стіна), природних об'єктів, які 
підвищуються над земною поверхнею (гора, пагорб), отворів у спорудах, проїздів або проходів між будівлями, які зачиняються / відчиняються (вікно, двері, ворота), огорож (тин, паркан, ліса), зворотних сторін локативних орієнтирів (борт), різноманітних предметів побуту та їхніх частин (крісло, шифоньєр, буфет, піч), частин, деталей одягу, взуття (комір, поясок, ремінь, халява), різноманітних об'ємних предметів, у яких фіксується зворотний бік щодо спостерігача (дерево, дуб, бузок), загальнопросторових понять на взірець рiг, поворот: ... [генеральша] з'явилася із-за сарайчика (Ю. Бедзик); ... 3-за пагорба вирвався наш яструбок (О. Десняк); А баба Дмитриха кричить із-за воріт (В. Стефаник); Тарас Григорович ... витягав з-за халяви ... книжечку (З. Тулуб); ... лунає з-за дерева ... окрик (О. Гончар); ... пробігли з-за рогу автомобілі (М. Семенко).

Вторинні прийменники відрізняються від первинних тим, що здатні перебирати на себе роль показника конкретного типу локативності. Підтвердженням цього можуть бути співвідносні з морфологізованими прислівниками прийменники вздовж / уздовж, вдовж / удовж, вподовж / уподовж, впоперек / упоперек, поперек, які є одним із заповнювачів правобічної позиції речень із транзитивною і статичною детермінацією. Ці препозиціональні компоненти зберігають свій значеннєвий зв'язок з тими адвербіальними лексемами, на базі яких виформувалися. Пор. вздовж / уздовж, вдовж / удовж, вподовж / уподовж, прийм.: Уживаються при вказівці на спрямованість дії по довжині чогось - присл.: У напрямку по довжині; у довжину чого-небудь (Білодід, 1979, т. Х: 406; Білодід, 1970, т. I: 312, 753); впоперек / упоперек, поперек, прийм.: Уживаються при означенні напряму за шириною чого-небудь - присл.: У ширину чого-небудь (Білодід, т. I, 1970: 753; Білодід, 1973, т. VI: 191).

Специфічною характеристикою речень, які входять до структурних субмоделей Sub + Praed + Adv [ВЗДОВЖ / УЗДОВЖ + Ngen] loc [trans], Sub + Praed + Adv [ВДОВЖ / УДОВЖ + Ngen] loc [trans], Sub + Praed + Adv [ВПОДОВЖ / УПОДОВЖ + Ngen] loc [trans], Sub + Praed + Adv [ВЗДОВЖ / УЗДОВЖ + Ngen] loc [stat], Sub + Praed + Adv [ВДОВЖ / УДОВЖ + Ngen] loc [stat], Sub + Praed + Adv [ВПОДОВЖ / УПОДОВЖ + Ngen] loc [stat] і передають семантику «носій процесуальної ознаки + процесуальна ознака + місце реалізації процесуальної ознаки: дія відбувається в просторі, що має протяжність 
у довжину», слід вважати те, що в них у припредикатній позиції функціюють іменники з яскраво заманіфестованою параметричною ознакою «довжина». 3-поміж них виокремлено лексеми - найменування наземних та водних шляхів сполучення (дорога, траса, шлях, колія, вулиия, шосе, стежка, ріка, брід, коридор), вертикально розташованих предметів, яким властива лінійна протяжність (стіна, мур, огорожа, паркан, тин, борт, байдак (заст.), вітрина), неорганізованих або організованих сукупностей людей, розміщених у певній послідовності, вишикуваних в один ряд, один за одним на певній дистанції тощо (натовп, юрба, юрма (розм.), товпа (розм.), юрмище (розм.), юрмисько (розм.), гурба (заст.), шеренга, стрій, колона, черга): ... [Докія] очима проводить його вздовж Великого шляху (М. Стельмах); Лейба ... позирав уподовж річки (Панас Мирний); Багато селян простує вподовж колії (В. Барка); Борис ... їі ... повів вздовж коридора (О. Десняк); Вздовж паркана котиться ... колесо (С. Тудор); Вона ... пішла вздовж ... муру (Ю. Мушкетик); Ми пливли вдовж сірих скель (М. Коцюбинський); Щорс ... пішов уздовж шеренги (О. Довженко); ... дерево лежало вздовж ріки (В. Гжицький); Уздовж лісу сіріло ...щиось (В. Собко); Вздовж яру висаджує він ті дерева (Ю. Смолич); Вони вишикувалися ... вздовж межі (І. Багряний); .. вподовж неї [річки] табунилось ... село (О. Гончар); Уздовж берега з води стриміли чотири модринові палі (М. Дочинець).

Характерною особливістю речень, які реалізують значення «носій процесуальної ознаки + процесуальна ознака + місце реалізації процесуальної ознаки: дія відбувається в просторі, що має протяжність у ширину» і $є$ конкретними репрезентантами структурних субмоделей Sub + Praed + Adv [ВПОПЕРЕК / УПОПЕРЕК + Ngen] loc [trans], Sub + Praed + Adv [ПОПЕРЕК + Ngen] loc [trans], Praed + Adv [ВПОПЕРЕК / УПОПЕРЕК + Ngen] loc [stat], Sub + Praed + Adv [ПОПЕРЕК + Ngen] loc [stat], слід вважати те, що лексико-семантичний склад репрезентантів припредикатної позиції в них обмежений іменниками - найменуваннями локативних понять, яким притаманна параметрична ознака «ширина». Це назви лімітованих просторів відкритого типу, невеликих акваторій, плантацій, деяких функційних територій і т. ін.: Човни пливли впоперек ріки (М. Трублаїні); Міряльник ... ішов впоперек поля (О. Кундзіч); ... [корчі] Мержинського ... повернули впоперек ліжка (М. Олійник); Він [ішов] ... поперек долини 
(Ю. Яновський); Смерека ... Лежала ... поперек річки (Л. Первомайський); ... [ліс] творить зелений мур поперек широкої площцини (О. Кобилянська); Степанове ліжко стояло впоперек кімнати (П. Загребельний); Скільки я його потовк упоперек сідла (І. Багряний).

Маркером значень «повздовжній шлях» / «повздовжнє місце», «поперечний шлях» / «поперечне місце» $є$ фактично прийменники вздовж / уздовж, вдовж / удовж, вподовж / уподовж, впродовж / упродовж, впоперек / упоперек, поперек, а не параметричні характеристики «довжина», «ширина», довкола яких інтегруються іменники-заповнювачі припредикатної позиції.

\section{Висновки}

Правобічний поширювач речень структурної моделі Sub + Praed + Adv loc, які репрезентують статичну, директивну й транзитивну семантику, виконує роль одного з важливих маркерів локативності. Своїм значеннєвим обсягом припредикатний компонент суттєво впливає на формування диференційованого значення. Ідеться передусім про план змісту іменникового компонента. Невід'ємним складником правобічної позиції, яку програмують дієслова-предикати, є також прийменники. Вони виконують роль посередника між дієсловом-предикатом і керованою формою субстантива. Органічно входячи до семантичної структури поширювача Adv loc, отже, і речення загалом, прийменники зберігають за собою роль ідентифікатора тієї або тієї просторової семантики. Мовиться насамперед про вторинні прийменники, які вирізняються своїми конститутивними властивостями, оскільки нерідко постають як основні виразники конкретного місця дії, напряму або шляху руху.

\section{ЛІТЕРАТУРА}

1. Білодід, І. К. (Ред.). (1970-1980). Словник украйнськоїмови. (Т. 1-11). Київ: Наук. думка. 2. Булаховський, Л. А. (Ред). (1951). Курс сучасної української літературної мови. (Т. 2). Київ: Рад. шк. 3. Вихованець, І. Р. (1971). Синтаксис знахідного відмінка в сучасній украӥнській літературній мові. Київ: Наук. думка. 4. Вихованець, І., \& Городенська, К. (2004). Теоретична морбологія української мови. Київ: Пульсари. 5. Всеволодова, М. В., \& Владимирский, Е. Ю. (1982). Способы выражения пространственных отнотений в современном русском языке. Москва: Рус. яз. 6. Колодяжний, А. С. (1960). Прийменник: матеріали до лекиій з курсу сучасної української літературної мови. Харків: Вид-во Харк. ун-ту. 7. Никитина, С. Е., \& Ярцева, В. Н. (Ред.). (1979). О семантическом варьировании русских предлогов: Предмет, задачи и способ описания. Семантическое и формальное варьирование. Москва: Наука. 


\section{REFERENCES}

1. Bilodid, I. K. (Ed.). (1970-1980). Slovnyk ukrainskoi movy [Dictionary of the Ukrainian language]. (Vol. 1-11). Kyiv: Nauk. dumka [in Ukrainian]. 2. Bulakhovskyi, L. A. (Ed.). (1951). Kurs suchasnoi ukrainskoi literaturnoi movy [Course of modern Ukrainian literary language]. (Vol. 2). Kyiv: Rad. shk. [in Ukrainian]. 3. Vykhovanets, I. R. (1971). Syntaksys znakhidnoho vidminka $v$ suchasnii ukrainskii literaturnii movi [Syntax of the accusative case in the modern Ukrainian literary language] Kyiv: Nauk. dumka [in Ukrainian]. 4. Vykhovanets, I., \& Horodenska, K. (2004). Teoretychna morfolohiia ukrainskoi movy [Theoretical morphology of the Ukrainian language]. Kyiv: Pulsary [in Ukrainian]. 5. Vsevolodova, M. V., \& Vladimirskij, E. Yu. (1982). Sposoby vyrazheniya prostranstvennyx otnoshenij $v$ sovremennom russkom yazyke [Ways of expressing spatial relationships in Modern Russian]. Moskva: Rus. yaz. [in Russian]. 6. Kolodiazhnyi, A. S. (1960). Pryimennyk: materialy do lektsii z kursu suchasnoi ukrainskoi literaturnoi movy [Preposition: materials for lectures on the course of modern Ukrainian literary language]. Kharkiv: Vyd-vo Khark. un-tu [in Ukrainian]. 7. Nikitina, S. E., \& Yarceva, V. N. (Eds.). (1979). O semanticheskom var'irovanii russkix predlogov: Predmet, zadachi i sposob opisaniya. Semanticheskoe $i$ formal'noe var'irovanie [On the semantic variation of Russian prepositions: subject, tasks and method of description]. Moskva: Nauka [in Russian].

Степаненко Микола Іванович - доктор філологічних наук, професор, ректор, Полтавський національний педагогічний університет імені В. Г. Короленка; вул. Остроградського, 2, Полтава, 36000, Україна.

Tel.: +38-097-390-49-21

E-mail: myk_ivan@ukr.net

http://orcid.org/0000-0002-6727-1265

Stepanenko Mykola Ivanovych - Doctor of Philological Sciences, Professor, Rector of V. H. Korolenko Poltava National Pedagogical University; 2 Ostrohradskoho Str., Poltava, 36000, Ukraine.

Надійшла до редакції 17 грудня 2020 року

\section{CITATION}

ДСТУ 8302:2015: Степаненко М. І. Правобічний поширювач у функції маркера локативної семантики на реченнєвому тлі. Лінгвістичні дослідження: зб. наук. пр. Харк. нац. пед. ун-ту імені Г. С. Сковороди. Харків, 2021. Вип. 54. Ч. І. С. 60-75. DOI: https://doi.org/10.34142/23127546.2021.54.1.06

APA: Степаненко, M. I. (2021). Правобічний поширювач у функції маркера локативної семантики на реченнєвому тлі. Лінгвістичні дослідження, 54 (I), 60-75. DOI: https://doi.org/10.34142/23127546.2021.54.1.06 